\title{
Pertumbuhan Planlet Lidah Mertua (Sansevieria sp.) Blue Leaf dari Kultur Kalus
}

\author{
DIAH RATNADEWI*, AI NURHASANAH HUSNUL IZZATI, ARIS TJAHJOLEKSONO
}

\author{
Departemen Biologi, Fakultas Matematika dan Ilmu Pengetahuan Alam, \\ Institut Pertanian Bogor, Kampus Dramaga, Bogor 16680
}

Diterima 1 Desember 2014/Disetujui 8 Januari 2015

\begin{abstract}
Lidah mertua (Sansevieria sp.) Blue Leaf is a slow growing ornamental plant. It is also difficult to reproduce. Therefore market demands for this plant is impossible to fulfill through conventional methods of propagation such as leaf cutting or layering. Tissue culture is one of the alternatives to solve the problem of plant propagation. In vitro culture of Sansevieria calli was induced for shooting, and rooting afterwards. The basic media of WP was superior than MS in producing multiple shoots, and this WP media containing of BAP $5 \mathrm{mg} / \mathrm{L}$ and NAA 0,5 mg/L (WH1) gave the highest number of shoots and leaves on plantlets, as well as the best growth performance. The shoots started to appear two weeks after culture. Plantlets from WH1 rooted in higher frequency as well on rooting media. A mixture of compost, sand, and zeolit $(4: 4: 1)$ enriched with a nutritive solution, composting of $1 / 4 \mathrm{WP}$ plus IBA $0.5 \mathrm{mg} / \mathrm{L}$, was a poreous media that was able to induce rooting of this plant.
\end{abstract}

Key words: kultur kalus, Sansevieria sp. Blue Leaf, planlet berakar

\section{PENDAHULUAN}

Dalam marga Agavaceae, Sansevieria adalah salah satu dari sekurangnya 60 jenis herba rimpang, berdaun tegak, tersusun secara roseta serta tidak bertangkai (Yuzzami et al. 2010). Karena bentuk, ukuran serta warna daunnya yang sangat beragam, tanaman Sansevieria banyak diminati sebagai tanaman hias. Selain itu, akhir-akhir ini tanaman Sansevieria dikenal mampu menyerap polutan udara. Jenis Sansevieria Blue Leaf belum teridentifikasi secara jelas nama spesiesnya, meskipun memiliki kemiripan dengan $S$. pinguiculata, yang bernilai komersial tinggi. Sebagaimana dengan Sansevieria lainnya, tanaman ini lazim diperbanyak hanya dengan stek daun yang membutuhkan jumlah tanaman induk yang banyak. Cara tersebut tidak memadai untuk memenuhi kebutuhan pasar karena pertunasan dan pertumbuhan tanaman dari stek daun sangat lambat. Teknik kultur jaringan diharapkan dapat mengatasi masalah perbanyakan tanaman ini; melalui kalus diharapkan dapat diperoleh sejumlah cukup besar planlet yang tumbuh sebagai tunas adventif, dan adanya kemungkinan variasi fenotipik pada tanaman hias daun akan memperluas ragam morfologi yang diharapkan.

*Penulis korespondensi. Phone/Fax: +62-251-8622833, E-mail: diahbiologi.ipb@gmail.com

\section{BAHAN DAN METODE}

Bahan eksplan yang digunakan adalah kalus Sansevieria Blue Leaf usia 6-7 bulan dari kultur daun, yang dipelihara secara aseptik dalam medium MS (Murashige dan Skoog 1962) yang diperkaya dengan Benzyl Amino Purine (BAP) $10 \mathrm{mg} / \mathrm{L}$ dan Naphtalene Acetic Acid (NAA) $0.5 \mathrm{mg} / \mathrm{L}$. Selama dua minggu, kalus tersebut dipelihara di dalam media MS atau Woody Plant (WP, Lloyd \& McCown 1981) tanpa zat pengatur tumbuh (zpt) untuk menetralkan pengaruh zpt dari media sebelumnya.

Untuk menginduksi pertunasan, kalus dibelahbelah dengan ukuran kurang lebih $1 \times 1 \mathrm{~cm}^{2}$ secara aseptik, lalu ditanam dalam media pertunasan. Media ini mengandung unsur mineral dan vitamin MS atau WP, yang masing-masing dikombinasikan dengan NAA $0.5 \mathrm{mg} / \mathrm{L}$ berfungsi sebagai media dasar. Kedua jenis media dasar tersebut diperkaya dengan BAP dengan dua tingkat konsentrasi (5 dan $7 \mathrm{mg} / \mathrm{L}$ ). Media-media pertunasan diberi nama MH1 (MS + BAP $5 \mathrm{mg} / \mathrm{L}$ ), MH2 (MS + BAP $7 \mathrm{mg} / \mathrm{L}$ ), WH1 (WP + BAP $5 \mathrm{mg} / \mathrm{L}$ ) dan $\mathrm{WH} 2$ (WP + BAP $7 \mathrm{mg} / \mathrm{L}$ ).

Untuk perakaran, digunakan media cair $1 / 4 \mathrm{MS}$ atau $1 / 4 \mathrm{WP}$ yang mengandung $0.5 \mathrm{mg} / \mathrm{L}$ Indole Butyric Acid (IBA). Sebanyak $25 \mathrm{~mL}$ larutan media tersebut dituangkan ke dalam campuran pasir, kompos, dan zeolit steril dengan perbandingan $4: 4$ : 1 di dalam botol kultur secara aseptik. 
Kultur dipelihara di ruangan bersuhu $\pm 25{ }^{\circ} \mathrm{C}$ dengan intensitas cahaya 1000 lux selama 16 jam per hari.

\section{HASIL}

Di dalam media pertunasan, eksplan berupa potongan kalus bertekstur kompak menunjukkan pertumbuhan kalus baru berwarna hijau kekuningan. Pertumbuhan tunas-tunas diamati mulai minggu kedua. Media WP + BAP 7 mg/L (WH2) memerlukan waktu paling lama untuk bertunas, yakni 8 minggu setelah tanam (MST), namun rentang proses rediferensiasinya juga paling panjang, hingga 19 MST. Kisaran waktu tumbuh tunas pada kalus serta rerata jumlah tunas disajikan di Tabel 1.

Tunas lebih banyak tumbuh pada kalus yang ditanam pada media WP dibandingkan dengan media MS, dengan frekuensi yang tidak berbeda antara konsentrasi BAP 5 dan $7 \mathrm{mg} / \mathrm{L}$. Tampilan fisik tunas dari kedua media dasar tersebut juga terlihat berbeda; tunas pada media WP lebih hijau daripada tunas pada media MS. Pada 23 MST, beberapa perlakuan menghasilkan tambahan tunas lagi, menyertai bertambah besarnya ukuran tunas, jumlah daun serta panjang daunnya. Tabel 2 menunjukkan hal tersebut. Dilihat dari tunas yang dihasilkan serta laju pertumbuhannya, media dasar WP lebih unggul daripada media MS dalam hal jumlah tunas, jumlah daun serta panjang daun. Perlakuan WH1 (WP dasar dengan BAP $5 \mathrm{mg} / \mathrm{L}$ ) menghasilkan rerata jumlah tunas tertinggi, yaitu 9, dengan rerata jumlah daun 9 (kisaran 8 hingga 19 helai daun) per tunasnya, dan

Tabel 1. Pertumbuhan tunas adventif pada kalus Sansevieria sp. Blue Leaf

\begin{tabular}{ccc}
\hline Perlakuan* & $\begin{array}{c}\text { Waktu muncul tunas } \\
\text { (MST) }\end{array}$ & \% Kultur bertunas** \\
\hline MH1 & $2-8$ & 20 \\
MH2 & $2-11$ & 10 \\
WH1 & $2-7$ & 70 \\
WH2 & $8-19$ & 60 \\
\hline
\end{tabular}

* Perlakuan $\mathrm{M}=$ media $\mathrm{MS} ; \mathrm{W}=$ media $\mathrm{WP} . \mathrm{H} 1=\mathrm{BAP} 5 \mathrm{mg} / \mathrm{L}$; $\mathrm{H} 2$ = BAP $7 \mathrm{mg} / \mathrm{L}$. ${ }^{* *}$ Pengamatan pada $20 \mathrm{MST}$ (Minggu Setelah Tanam). panjang daun rerata $1.5 \mathrm{~cm}$; sedangkan perlakuan WH2 (WP dasar dengan BAP $7 \mathrm{mg} / \mathrm{L}$ ) berada di urutan kedua dengan jumlah 7 tunas, rerata 7 helai daun per tunas (kisaran 5-15 helai). Pada media dasar MS, tunas yang dihasilkan sangat sedikit. Tunas tunggal dari $\mathrm{MH} 2$ memanjang lebih cepat dengan munculnya 17 helai daun pada minggu ke 23. Gambar $1(\mathrm{a}, \mathrm{b}, \mathrm{c}, \mathrm{d})$ menyajikan urutan pertumbuhan tunas pada kalus hingga tampak tunas dengan dedaunan yang terbuka penuh.

Untuk fase perakaran, planlet yang tumbuh baik, yaitu yang daunnya terbuka penuh, berwarna hijau dan panjang minimumnya $1.5 \mathrm{~cm}$, dipisahkan dari eksplan induknya. Lalu tunas tersebut ditanam pada media $1 / 4 \mathrm{WP}$ semi padat (dengan $7 \mathrm{~g} / \mathrm{L}$ agar) yang mengandung IBA $0.5 \mathrm{mg} / \mathrm{L}$. Berbeda dengan proses pertunasan, perakaran tidak terjadi samasekali pada medium tersebut. Hal itu mendorong dilakukannya modifikasi pada bentuk mediumnya, yaitu dengan menggunakan campuran kompos:pasir malang:zeolit (4:4:1) steril di dalam botol kultur, yang kemudian dituangi dengan larutan steril media cair $1 / 4 \mathrm{WP}$ atau $1 / 4 \mathrm{MS}$ yang mengandung IBA $0.5 \mathrm{mg} / \mathrm{L}$. Pada $8 \mathrm{MST}$ di media perakaran ini, diperoleh hasil sebagaimana tertera di Tabel 3.
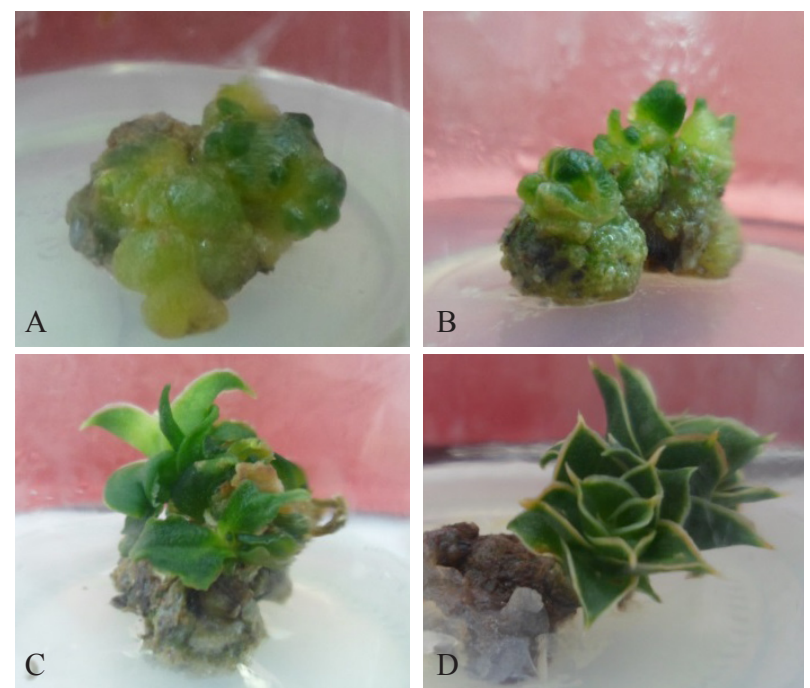

Gambar 1. Proses pertumbuhan tunas pada kalus Sansevieria sp. Blue Leaf pada media MH1. A. Kalus organogenik 6 MST; B. Tunas mulai tampak, 8 MST; C. Tunas yang membesar, 16 MST; D. Tunas dengan daun terbuka penuh, $18 \mathrm{MST}$.

Tabel 2. Pertumbuhan tunas Sansevieria sp. Blue Leaf*

\begin{tabular}{ccccc}
\hline \multirow{2}{*}{ Perlakuan } & \multirow{2}{*}{ Jumlah Tunas** } & Tinggi Tunas $(\mathrm{cm})$ & Jumlah Daun (helai) & Panjang Daun $(\mathrm{cm})$ \\
\cline { 3 - 4 } & & Rerata & Rerata & Rerata \\
\hline MH1 & 2 & $0,45 \pm 0,14$ & $3 \pm 1,23$ & $0,80 \pm 0,27$ \\
MH2 & 1 & $0,90 \pm 0,34$ & $17 \pm 7,10$ & $1,00 \pm 0,44$ \\
WH1 & 9 & $0,78 \pm 0,28$ & $9 \pm 3,43$ & $1,50 \pm 0,54$ \\
WH2 & 7 & $0,71 \pm 0,26$ & $7 \pm 2,94$ & $1,20 \pm 0,44$ \\
\hline
\end{tabular}

* Pengamatan pada 23 MST (Minggu Setelah Tanam). ** Jumlah tunas total dari 10 kultur. 
Tabel 3. Pertumbuhan akar pada planlet Sansevieria sp. Blue Leaf di media modifikasi

\begin{tabular}{cccccc}
\hline \multirow{2}{*}{ Media asal planlet } & \% planlet berakar & $\begin{array}{c}\text { Jumlah akar } \\
\text { utama }\end{array}$ & $\begin{array}{c}\text { Panjang akar } \\
\text { utama }(\mathrm{cm})\end{array}$ & Jumlah akar lateral & $\begin{array}{c}\text { Panjang akar } \\
\text { lateral }(\mathrm{cm})\end{array}$ \\
\cline { 3 - 6 } & & Rerata & Rerata & Rerata & Rerata \\
\hline WH1 & 55.6 & $1,60+0,89$ & $1,30+0,59$ & $2,00+1,22$ & $0,73+0,55$ \\
WH2 & 42.9 & $1,33+0,58$ & $2,22+1,09$ & $1,67+0,58$ & $0,58+0,10$ \\
\hline
\end{tabular}

Pengamatan pada 8 MST.

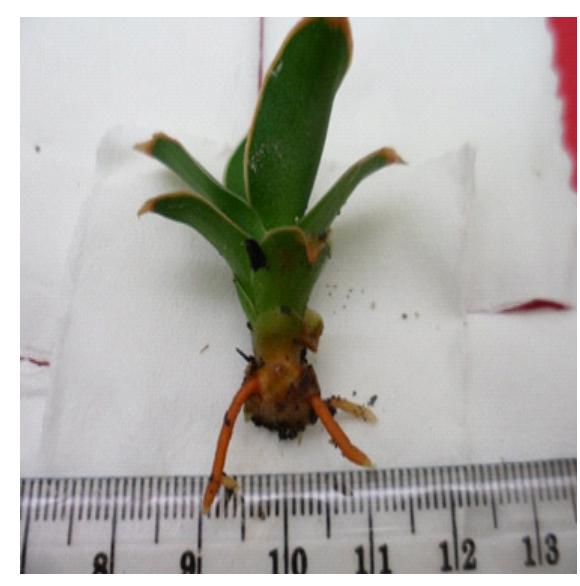

Gambar 2. Planlet berakar pada 8 MST.

Berdasarkan kriteria tersebut di atas, hanya planlet dari media pertunasan WH1 dan WH2 yang dapat dipindahkan ke media perakaran hasil modifikasi tersebut, yaitu dengan sumber nutrisi $1 / 4$ WP dan $0,5 \mathrm{mg} / \mathrm{L}$ IBA. Pada fase perakaran, planlet dari WH1 mampu berakar dengan frekuensi lebih tinggi daripada planlet dari media WH2. Akar lateral kemudian bermunculan dari akar adventif utama tersebut. Planlet berakar dapat dilihat pada Gambar 2.

\section{PEMBAHASAN}

Sansevieria sp. Blue Leaf termasuk tanaman yang sulit diperbanyak dan lambat pertumbuhannya. Anggota dari marga Agavaceae ini terdiri atas sejumlah spesies yang beragam sifat propagasinya. S. cylindrica seperti halnya Sansevieria Blue Leaf, termasuk spesies yang sulit propagasinya, sedangkan $S$. trifasciata termasuk lebih mudah karena menghasilkan rimpang cukup intensif, dan kemudian tunas-tunas tumbuh dari rimpang tersebut. Secara fisik, Sansevieria Blue Leaf mirip dengan $S$. pinguiculata, tanaman hias yang telah lebih dulu digemari masyarakat dan harganya tinggi.

Media dasar WP lebih baik daripada media MS untuk menumbuhkan tunas-tunas pada kalus secara organogenesis. Media WP yang diperkaya dengan NAA $0.5 \mathrm{mg} / \mathrm{L}$ dan BAP $5 \mathrm{mg} / \mathrm{L}$ mampu menghasilkan tunas terbanyak, dengan jumlah daun dan panjang daun yang unggul pula. Media dasar MS sangat kaya secara mencolok akan kandungan nitrogen; dalam bentuk $\mathrm{NH}_{4} \mathrm{NO}_{3}$ dan $\mathrm{KNO}_{3}$, unsur $\mathrm{N}$ dalam media MS sekitar tujuh kali lipat dari $\mathrm{N}$ dalam media WP. Media WP memiliki kelebihan pada kandungan sulfur dari $\mathrm{K}_{2} \mathrm{SO}_{4}$ dibandingkan dengan media MS. Unsur mineral lainnya relatif tidak berbeda, serta vitamin yang digunakan dalam kedua jenis media tersebut sama. Kandungan nitrogen yang lebih rendah pada media WP menyebabkan tunas terlihat lebih kekar dan kompak. Ini menandakan bahwa kandungan $\mathrm{N}$ dalam media MS terlalu berlebihan bagi pertumbuhan Sansevieria sp. Blue Leaf. Hal tersebut didukung pula oleh hasil penelitian Winarto (2004), yang menggunakan media dengan kandungan $\mathrm{N}$ total lebih rendah, menghasilkan tunas-tunas tanaman anyelir tumbuh lebih banyak dan terlihat lebih vigor. Kumar dan Kumar (2008) melaporkan bahwa: Sulfur berpengaruh meningkatkan sintesis klorofil pada tanaman pisang Cavendish. Tambahan lagi, sulfur merupakan komponen penting dari berbagai senyawa penggerak metabolisme sel tumbuhan, antara lain tioreduksin yang berperan dalam reaksi terang fotosintesis, serta menjadi bagian dari asam amino sistein dan metionin (Salisbury dan Ross 1995).

Planlet Sansevieria sp. Blue Leaf tampaknya membutuhkan aerasi untuk menginisiasi akar, yang diberikan oleh media campuran antara kompos, pasir malang dan zeolit (4:4:1) yang dilembabkan dengan larutan $1 / 4$ WP yang mengandung IBA 0.5 $\mathrm{mg} / \mathrm{L}$. Perakaran seringkali menjadi masalah dalam perbanyakan vegetatif tanaman. Faktor-faktor yang berperan dalam inisiasi akar adventif antara lain: kuantitas dan kualitas radiasi cahaya, drainase dan kecukupan aerasi di daerah perakaran pada media tumbuhnya. Pijut et al (2011) menjelaskan bahwa naungan dapat memperbaiki kemampuan berakar pada stek batang setelah bagian aerialnya mendapatkan cukup cahaya untuk melakukan fotosintesis dan penimbunan karbohidrat. Senyawa fenolat dikenal sebagai pemacu atau penghambat internal untuk pembentukan akar adventif. Pemberian cahaya merah dari diode pemancar-cahaya (LED) pada planlet in vitro Protea cynaroides, meningkatkan perakaran hingga $67 \%$ dibandingkan bila mendapatkan cahaya putih lampu neon biasa dengan hasil $7 \%$ saja. Pada saat bersamaan cahaya merah tersebut berpengaruh menurunkan kandungan senyawa fenolat pada planlet 
yang akhirnya berhasil menginduksi tumbuhnya akar (Wu dan Lin 2012).

Untuk memperbaiki aerasi di daerah perakaran, dalam penelitian ini telah dicoba untuk meningkatkan porositas media tanam planlet. Media modifikasi semacam ini lazim disebut media in vitro soil-less (IVS). Newell et al. (2003) berhasil menginduksi tumbuhnya akar dan pemanjangan akar selanjutnya pada tanaman Grevillea thelemanniana dan tanaman hasil persilangan antara Verticordia plumosa dan Chamelaucium uncinatum menggunakan media campuran antara sphagnum peat, pasir sungai (1-3 $\mathrm{mm}$ ) dan perlite dengan perbandingan 0.5:2:2 yang ditambah kapur pertanian (horticultural lime) $2 \mathrm{~g} / \mathrm{L}$. Penggunaan media dari partikel padat semacam ini juga menciptakan kondisi terlindung dari cahaya di daerah perakaran sementara bagian tajuknya masih mendapatkan cukup cahaya untuk fotosintesis.

Secara umum dapat disimpulkan bahwa media dasar WP lebih cocok untuk tumbuhnya tunas pada kalus Sansevieria sp. Blue Leaf daripada media MS. Perlakuan WH1, yaitu WP dengan NAA $0.5 \mathrm{mg} / \mathrm{L}$ dan BAP $5 \mathrm{mg} / \mathrm{L}$ lebih unggul dalam menghasilkan jumlah tunas, jumlah daun per tunas serta pertumbuhan selanjutnya, dibandingkan dengan perlakuan lainnya. Planlet Sansevieria sp. Blue Leaf menghendaki media beraerasi yang diberikan oleh media campuran kompos, pasir malang, zeolit (4:4:1) untuk berakar, dibandingkan dengan media agar.

\section{DAFTAR PUSTAKA}

Kumar AR, Kumar N. 2008. Studies on the efficacy of sulphate of potash (SOP) on the physiological, yield and quality parameters of Banana cv. Robusta (Cavendish-AAA). EurAsia J Biosci 2:102-109.

Lloyd G, McCown B. 1981. Commercially feasible micropropagation of mountain laurel Kalmia latifolia by use of shoot tip culture. Comb Proc Intl Plant Prop Soc 1981, 30:421-427.

Murashige T, Skoog F. 1964. A revised medium for rapid growth and bioassays with tobacco tissue culture. Physiol Plant 15:473-497.

Newell C, Growns D, McComb J. 2003. The influence of medium aeration on in vitro rooting of Australian plant microcutting. PCTOC 75:131-142.

Pijut PM, Woeste KE, Michler CH. 2011. Promotion of adventitious root formation of difficult-to-root hardwood tree species. In: Janick J (ed.). Horticultural Reviews, Vol. 38. Wiley-Blackwell. p. 213-252.

Salisbury FB, Ross CW. 1995. Fisiologi Tumbuhan Jilid 3. Lukman DR, Sumaryono, penerjemah; Niksolihin S, editor. Bandung (ID): ITB Press. Terjemahan dari: Plant Physiology. Ed ke 4.

Winarto B. 2004. Modifikasi konsentrasi $\mathrm{NH}_{4} \mathrm{NO}_{3}$ dan $\mathrm{CaCl}_{2}$ medium MS terhadap pertumbuhan eksplan hiperhidristi anyelir. AgroSains 6:45-52.

Wu H-C, Lin C-C. 2012. Red light-emitting diode (LEDs) light irradiation improves root and leaf formation in difficult-topropagate Protea cynaroides L. plantlets in vitro. HortSci, 47:1490-1494.

Yuzzami, Witono JR, Hidayat S, Handayani T, Sugiarti, Mursidawati S, Triono T, Astuti IP, Sudarmono, Wawangningrum H. 2010. Ensiklopedia Flora Jilid I. Depok (ID): PT Kharisma Ilmu. 